\title{
Correction to: Limit Analysis Solutions for Bearing Capacity of Ring Foundations on Rocks Using Hoek-Brown Failure Criterion
}

\author{
Wittawat Yodsomjai $^{1}$. Suraparb Keawsawasvong ${ }^{1}$ (1) $\cdot$ Van Qui Lai $^{2,3}$
}

Published online: 10 June 2021

(c) The Author(s), under exclusive licence to Springer Nature Switzerland AG 2021

\section{Correction to: \\ International Journal of Geosynthetics and Ground Engineering (2021) 7:29 \\ https://doi.org/10.1007/s40891-021-00281-y}

This correction is published to notify errors in authors' affiliations. Please take note that changes have been made to authors, Suraparb Keawsawasvong and Van Qui Lai as below.

\section{Errata:}

The original version of this article:

Suraparb Keawsawasvong ${ }^{2,3}$. Van Qui Lai ${ }^{2}$.

Was altered as:

Suraparb Keawsawasvong ${ }^{1}$. Van Qui Lai ${ }^{2,3}$

The original article has been updated.
Publisher's Note Springer Nature remains neutral with regard to jurisdictional claims in published maps and institutional affiliations.

The original article can be found online at https://doi.org/10.1007/ s40891-021-00281-y.

Suraparb Keawsawasvong

ksurapar@engr.tu.ac.th

1 Department of Civil Engineering, Thammasat School of Engineering, Thammasat University, Pathumthani 12120,

Thailand

2 Faculty of Civil Engineering, Ho Chi Minh City University of Technology, (HCMUT), 268 Ly Thuong Kiet Street, District 10, Ho Chi Minh City, Viet Nam

3 Vietnam National University Ho Chi Minh City (VNU-HCM), Linh Trung Ward, Thu Duc District, Ho Chi Minh City, Vietnam 